\title{
Frontiers of Romania: Nationalism and the Ideological Space of the Roman Limes
}

\author{
Emily R. Hanscam
}

Dept. of Archaeology, Durham University

\begin{abstract}
Modern Romania is a nation-state containing space which has long been considered marginal - first as part of the Roman Empire and now within the European Union. The national narrative of Romania highlights this liminality, focusing on the interactions between the Romans and the local Dacians on the northeastern border regions of the Empire. Romania still contains significant material remnants of the Iron Age, including the Roman Limes, a series of fortifications on the Danube River meant to protect the Roman borders. As such, the archaeological tradition of this geographic space is heavily entangled with Romania's identity as a frontier region. This paper outlines the formation of Romanian national space, focusing on the period between the seventeenth century and 1918. It considers the relationship between the materiality of the Roman Limes and ideological frontiers in Romania, examining the role of archaeology in the sustainment of the Romanian nation space.
\end{abstract}

Keywords: Romania, Frontiers, Roman Limes, Ideological Space, Nationalism

\section{Introduction}

The foundation of the Romanian nation-state in the nineteenth century was a declaration that the intellectual elite of southeast Europe chose to orient themselves towards the West rather than the Ottoman East. Romania (Figs. 1, 2) achieved international recognition of political sovereignty in 1881, escaping subjugation by the Austro-Hungarian Empire and the Russian Empire as well as the Ottomans. This happened primarily because it suited the 'Great Powers' of France, Germany, and Great Britain to sponsor nation building in the Carpathians rather than permit the expansion of the aforementioned empires (Hitchins 1996; Boia 2001; Popa 2015). Romania has always been a multicultural space characterized by a need to distinguish itself from its immediate neighbors, and the country today has a prolific material past which is haunted by over a century of explicit politicization by the construction of particular archaeological narratives. This paper will begin by outlining the formation of Romanian national space until the end of the First World War in 1918, and then moves to compare the relationship between the materiality of the Roman Limes on the Lower Moesian Frontier, and the ideological frontier which I argue exists within Romania and Romanian archaeology. 
Popa (2015: 348) points out that presently,

[Romanian] scholars are not directly overtly politicizing their research", but rather that "the situation has reached a point where the nationalistic discourse is so subtle, so embedded in everyday archaeological practices and writing, that it becomes invisible to the authors and academic readers of that environment.

There are myriad reasons why this has occurred in Romania, and Romania is not at all alone in this. Every nation has at times promoted one historical narrative over another. ${ }^{1}$

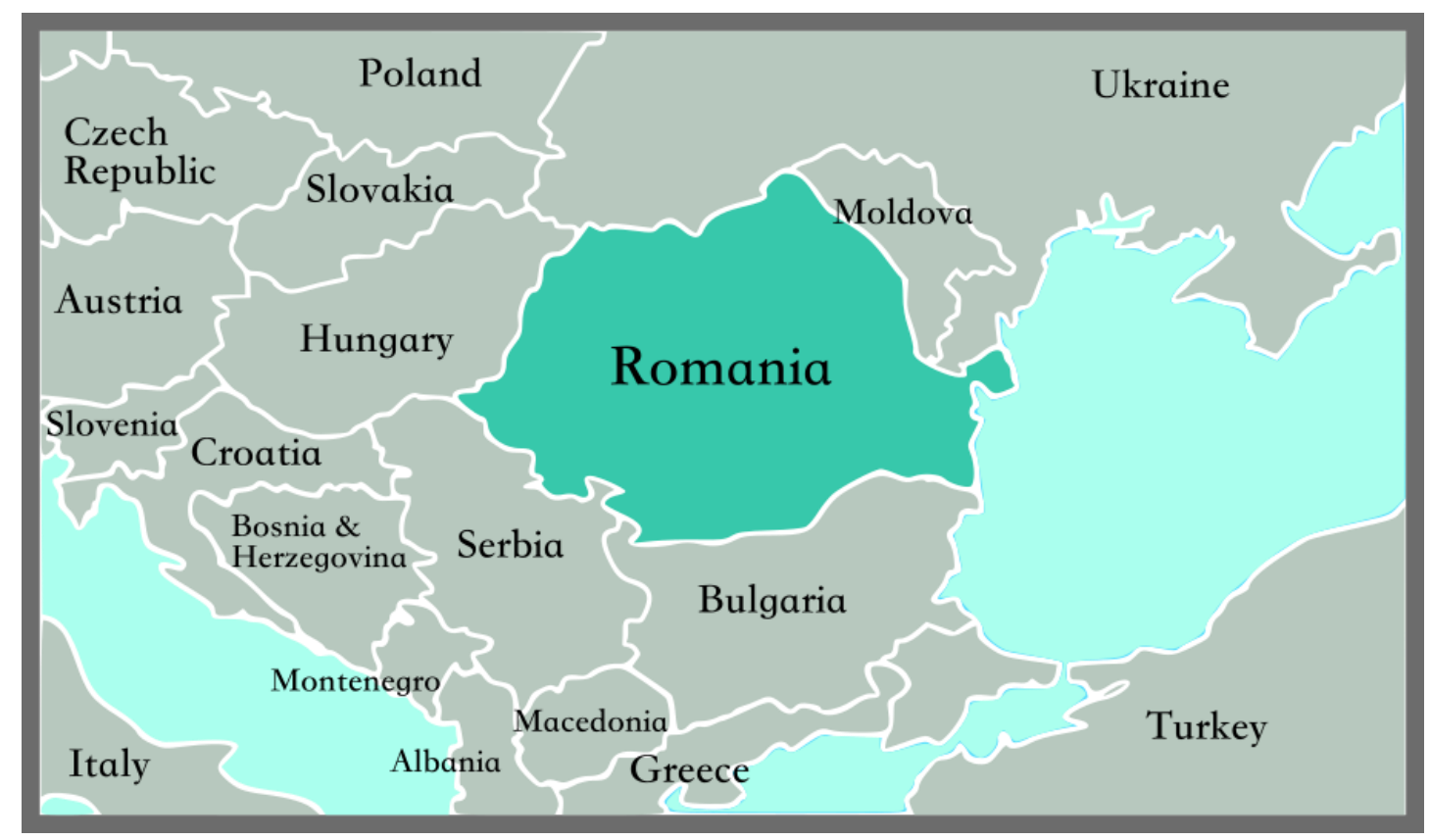

Figure 1. Romania highlighted within Eastern Europe (E. Hanscam)

Nationalism and archaeology developed hand-in-hand; as Díaz-Andreu and Champion (1996b: 3) write, "the appearance of nationalism stimulated the very creation of archaeology as a science ... [it] was a closed circle. The nation was at the same time the basis and the aim of research." Archaeology was simultaneously flexible enough to support imperialism by providing scientific evidence for the evolutionary hierarchy of peoples, thereby proving the necessity of the colonial world order (Trigger 2006). Academics have established a considerable dialogue on the archaeological work of the nineteenth century, work that inspired myths like ethnic nationalism (see e.g. Hobsbawm \& Ranger 1983; Kohl 1998; Thomas 2004; Lampe \& Mazower 2004; Anderson 2006; Díaz-Andreu 2008). Cultural-historical archaeology as a theory encouraged a focus on ethnicity, accommodating nationalist interpretations "where specific archaeological cultures were unproblematically seen as ancestral to contemporary ethnic or national groups" (Kohl 1998: 231).

\footnotetext{
${ }^{1}$ See e.g. Diaz-Andreu and Champion (1996) for a summary of nationalism and archaeology in Europe, Hamilakis (2007) for the relationship between the Greek national imagination and archaeological material, and Hingley (2000) for an example of the impact of the Roman past on British nationalism.
} 
Because of this, and in an attempt to "counteract the effects of unseen biases and inadequate research designs" (Trigger 2006: 546), archaeology is now a discipline intent on the pursuit of reflexivity, or the necessity of conducting socially aware research (e.g. Hamilakis 1996; Hodder 2005; McGuire 2008; Alberti et al. 2011; Watts 2013). Preucel and Meskell (2004: 16) define social archaeology as an approach that "engages with how different peoples inscribe meaning ... and through this process of inscription, construct themselves."

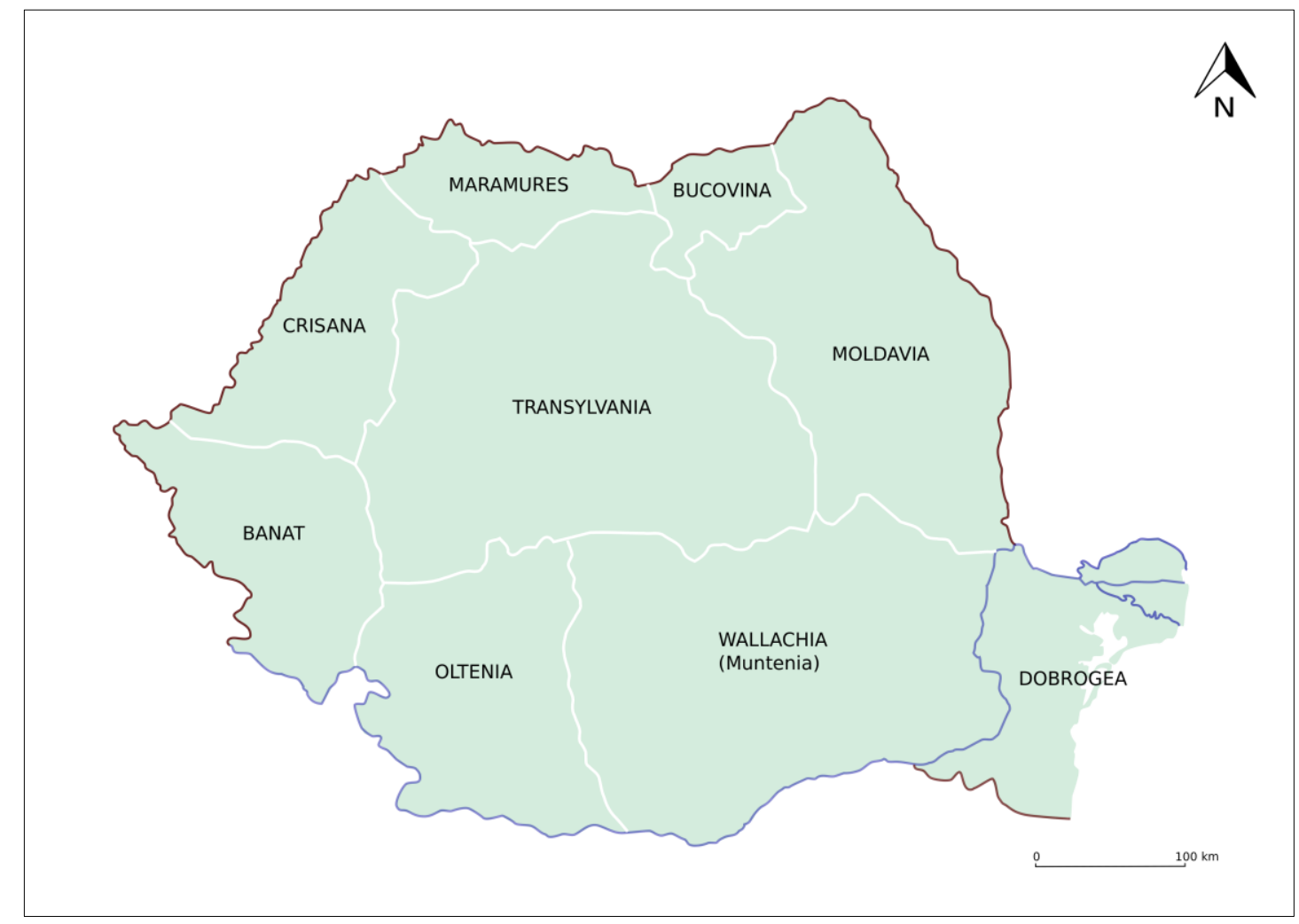

Figure 2. Historical regions of Romania (E. Hanscam)

The construction of self is key as it applies to those doing the research as well, we understand that archaeologists are actors creating the past through personal engagement with the material record, and we often criticize those who use this relationship to further political agendas. However some like McGuire (2008) advocate for archaeology as political action, while Yannis Hamilakis' (2017) recent work in understanding the materiality of the migrant crisis definitively calls for politically engaged scholarship. A decade ago, Trigger (2007: 547) said that archaeology is becoming an "increasingly effective basis for understanding social change." A great deal of social change has occurred in the past ten years, and archaeologists are a) engaging with extremely contemporary events (Gardner 2017), and b) struggling to understand how to research in a way that combats resurging nationalism without becoming overtly politicized. ${ }^{2}$ It is difficult, because we want to avoid creating a dichotomy between our own personal subjective views of how the past should be treated and those which further nationalist agendas.

2 A topic of much discussion following a session on social boundaries in the Roman world at the Theoretical Roman Archaeology Conference 2017 (Durham, 28-31 March). 
In some regions, like Romania, archaeology remains politicized in the old culturalhistorical sense and scholarship continues to (at times explicitly) support the nationalist agendas of the state. Texts which are otherwise rigorous include statements like

The territory inhabited by Romanians has a well-marked individuality that, on the whole, and in spite of its large variety and complexity, has a remarkable homogeneity and symmetry. Indeed, one may confidently assert that the unity of the land has much to do with the unity of the Romanian people (Spinei 2009: 13).

There are an increasing number of local and international commentaries on Romanian archaeology, which highlight advances being made. Popa (2015) provides a detailed analysis on the relationship between the Late Iron Age and politics in Romania, building on the work of scholars like Kaiser (1995), Niculescu (2002, 2004), Lockyear (2004), Dragoman (2009), and Enea (2012). Boia (2001) is the authority on the ideological construction of Romanian national history, an area in which Deletant (1991), Verdery (1991) Hitchins (1992), and Iordachi (2004) have also made significant contributions. But attitudes within the discipline can be very similar to those towards the country as a whole. Romania is marginalized within Europe, just as the Romanian archaeological tradition is subject to dismissal and criticism.

On January 1 ${ }^{\text {st }}, 2014$ the UK granted Romanians and Bulgarians free access to the UK labor market, inspiring a wave of xenophobia on the part of the British public, a wave which was reignited after Britain voted to leave the EU in June 2016. ${ }^{3}$ Romanians, despite their EU membership status, are continually seen as not quite European (and therefore undeserving of benefits such as access to jobs made available through the freedom of movement for workers). In a similar vein, Todorova (2009: 193-4) writes how discourses about the Balkans in general places the territory within a "cognitive straightjacket" propagating "aggressive, intolerant, barbarian, semi-developed, semicivilized, and semi-oriental" stereotypes. Romania, located on the margins of Europe bordering the East, is included within the Balkan discourse. Boia (2001: 186) writes, "we Romanians represent the first circle of otherness, sufficiently close for our curious configurations and disturbing forms of behavior to be highlighted all the more strongly by contrast . . .". Romania is a liminal space. If we generalize the disparate voices of Europe into a pan-European identity or European denationalization (eg. Sassen 2010), then Romania acts as a borderland separating Europe and the East. It is also a borderland within archaeology, a place where the past is still presented through a

\footnotetext{
${ }^{3}$ See eg. Petre, J \& Walters, S. Exposed: What they DIDN'T tell you about new wave of migrants heading for booming Britain, accessed 2 May 2017, http://www.dailymail.co.uk/news/article-2530503/Exposed-WhatDIDNT-tell-new-wave-migrants-heading-booming-Britain.html; The Guardian, Bulgarian and Romanian immigration bysteria 'fanned by far-right', accessed 2 May 2017, http://www.theguardian.com/uknews/2014/jan/03/romanian-bulglarian-uk-immigration-hysteria-far-right; Agerholm, H. Brexit: Wave of hate crime and racial abuse reported following EU referendum, accessed 2 May 2017, http://www.independent.co.uk/news/uk/home-news/brexit-eu-referendum-racial-racism-abuse-hatecrime-reported-latest-leave-immigration-a7104191.html.
} 
continued reliance on antiquated archaeological theories like Kossinna's culturalhistorical archaeology (Trigger 2006). Romania is not alone in this, Maran (2017: 21) points out that "most archaeological cultures of the Southeastern European Neolithic, Copper Age and Bronze Age are based on little more than the distribution of certain pottery features within the political borders of nation states;" and similarly, processual archaeology "is still a living tradition" for Mesolithic studies in Northern Spain (González Morales \& Fano Martínez 2005: 25).

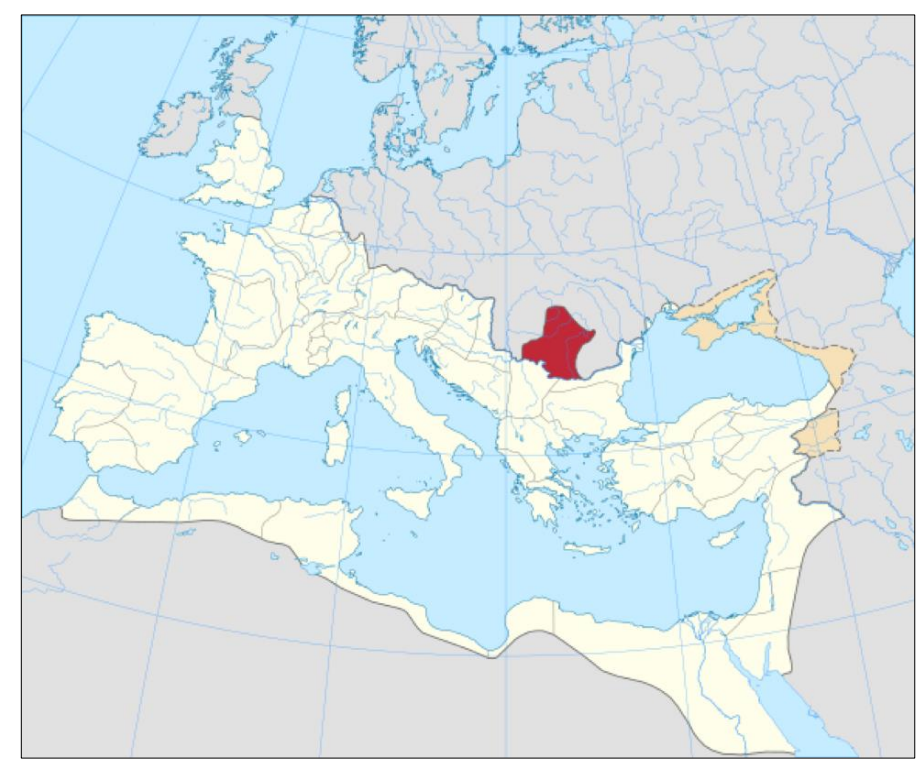

Figure 3. Roman Dacia highlighted on map of the Roman Empire, By Shadowxfox - Own work, CC BY-SA 4.0, https:// commons.wikimedia.org/w/index.php?curid $=45059715$

Romania was also a marginal region in antiquity. The Romans established the province of Moesia Inferior south of the Danube in the $1^{\text {st }}$ century CE (Fig. 3) and built a series of fortifications on the Danube River, known today as the Roman Limes of the lower Danube (Hanson \& Haynes 2004; Oltean 2008; MateiPopescu 2010; Zahariade \& Karavas 2015). They also tried, and failed, to hold the province of Dacia in the central Carpathian Mountains. ${ }^{4}$ This region resisted incorporation into the Roman Empire partially because of the continued pressure of migrating populations moving west from the Russian steppe. The Carpathian Gap, the lowlands between the Carpathian Mountains and the Black Sea, was a popular route into Europe for the steppe tribes of the $4^{\text {th }}-8^{\text {th }}$ centuries (Ellis 1998; Curta 2001). The Roman fortifications and legions could not withstand the continued pressure, leading eventually to the complete abandonment of the region. From a Roman-centric viewpoint, the provinces of Dacia and Moesia Inferior were vulnerable, being out on the margins of civilization. ${ }^{5}$ It is perhaps ironic that Romanian nationalism initially fixated on the Romans as the heroic ancestors who could bring stability, when stability was something they continually struggled to provide in antiquity.

In this paper I will argue for a new way of understanding both the ideological development of regions such as modern-day Romania, and the archaeological traditions of these spaces. As is explained below, the foundation of the Romanian nation-state

\footnotetext{
${ }^{4}$ Dacia was conquered by Trajan in $107 \mathrm{CE}$ and held until 271-275 when Aurelian organized a withdrawal south of the Danube.

5 There are a number of similarities with the Roman Frontier in Britain to the northwest, for a study on the impact of the Roman past to modern day Britain, see Hingley (2015).
} 
drew heavily on the Iron Age to find what Popa (2015: 339) terms the "tangible distinctiveness" necessary for national legitimacy. This, combined with the significant Iron Age material landscape (including the remnants of the Roman Limes), and the continued view of Romania as marginalized within Europe, creates a geographic space which continues to be entangled with the frontiers of antiquity. We can understand the relationship between people and space with theories like differential inclusion, which argues that as people move across borders, they experience places which are open to some but closed to others depending on their cultural background and identity (Richardson 2013). Romania has yet to face migratory pressures like other nations in southeast Europe, but this is not a precluded eventuality - it stands to reason that the region will once again host migrating populations. This has happened at multiple times in the past - in addition to the migrations of the $4^{\text {th }}-8^{\text {th }}$ centuries, the Carpathian Basin and lower Danube are also on one of the major proposed hominin migration routes (Mellars 2006). In 2002 Trinkaus et al. (2003) discovered the oldest (at the time) remains of anatomically modern humans in Europe in the Peştera cu Oase cave system, located in the southwest Carpathian Mountains. Given the likelihood of future migrations, we therefore need to question the creation and sustainment of ideological and cultural barriers in regions like Romania, in addition to promoting a more nuanced view of the archaeological traditions which contribute to the construction of this frontier space.

I will begin by detailing the formation of the Romanian national space focusing on the period between the seventeenth century and the establishment of Romania Mare (Greater Romania) in 1918. I will then consider the relationship between the materiality of the Roman Limes and ideological frontiers in Romania, aiming to theorize how border regions like Romania entangle themselves with the past. I will conclude with the need to understand nationalist archaeologies in terms of the cultural space they generate and sustain.

\section{The Formation of Romanian National Space}

The idea that descendants of $2^{\text {nd }}$ century Roman colonists still inhabited a region in southeastern Europe first appears in print in the seventeenth century, with the publication of two treatises written by pro-Polish Moldavian chroniclers. Grigore Ureche (ca. 1590-1647) and Miron Costin (1633-1691) both knew Latin and recognized the potential benefits of creating a lasting link between the Romanians and the Polish, who "formed a powerful potential ally for the $17^{\text {th }}$ Century Moldavians, for as the selfstyled 'last bastion of defense for Roman Christendom,' they might be expected to sympathize with the sons of Rome" (Verdery 1991: 324; cf. Hitchins 2001). Boia (2001: 129) agrees: "We find the ethnic unity of the Romanians, or at least their relatedness and common origin, affirmed as clearly as we could wish starting with Grigore Ureche." Because Latin was the language of culture throughout Europe at this time (Russia even considered itself the 'third Rome') any link to the Romans conveyed a sense of prestige. Ureche and Costin therefore "claimed a Romanian origin for Trajan's Roman colonists" (Verdery 1991: 324). 
Yet the popular dissemination of such a link was controversial, especially among the Orthodox priests, who were trying to resist the incursion of Catholicism. As Verdery (1991: 32) suggests, "those struggling to oppose the incursions of the 'Roman' faith did not, it seems, find a Roman origin wholly convenient." At this time the dispute remained was fixed within what Anderson (2007) calls "religiously imagined communities," largely as a matter of religious identity, as it was too early in the development of national thought for the notion of borders fixed by language and ethnicity. It did, however, combine the "two major components of the European tradition - the imperial and the Christian" (Mishkova 2015: 137). Byzantium played an important role as the lawful heir to the Roman Empire and the keeper of the Orthodox faith (Mishkova 2015); Ureche and Costin "emphasized the role and the greatness of the early Romanians as a separate nationality, albeit one that had been part of the Byzantine world" (Tanașoca 2002: 47). Tanaşoca (2014: trans. in Mishkova 2015: 138) elaborates: "in the spirit of the Romanian humanists of the $17^{\text {th }}$ and $18^{\text {th }}$ centuries the idea about Orthodox solidarity and the nostalgia for the Byzantine Empire goes along with a very strong feeling of national identity that acquires an important Byzantine dimension". The emphasis on the Byzantine Empire, which had only relatively recently fallen to the Turks in 1453, created a tangible connection to Rome while simultaneously rejecting anything Ottoman in these formerly Roman lands.

Unlike the nationalism of the late nineteenth and early-mid twentieth century, the idea of a Roman heritage for the peoples of Wallachia, Moldavia, and Transylvania meant that they were specifically promoting a non-autochthonous origin. Autochthonism is an interesting concept, which is not widely known outside of the social sciences. It is a specific brand of indigenism (or indigenous nationalism) which was popular in the former Ottoman lands in Eastern Europe: the autochthonist population was the people who could prove they were the first to inhabit a territory. Zenker (2011: 65) defines autochtony as the proclaimed original link between "individual, territory, and group." Romania, Bulgaria, and Hungary all have their autochothonist narratives, Romania's was found in the "application and negotiation of the alternative pasts of the Romans and Dacians" while Bulgaria worked with Thracian, proto-Bulgarian, and Slavic pre-history (Trencsényi 2010: 26; cf. Mishkova \& Daskalov 2014). Hungary, on the other hand, had a narrative of identity that focused on the Huns, thus attempting to "undermine the classical pedigree of their competitors" (Trencsényi 2010: 26). Likewise, de Francesco (2013) details the calls within nineteenth century Italy for identities with privilege derived from Roman ancestry, or links to peoples from the pre-Roman era like the Etruscans. Smith (1986: 183) notes how "in the myths of the community its origins reach back into a mysterious and primordial time." This lack of clarity, useful in the sense that it thereby makes it difficult to disprove, is particularly challenging when there is a corresponding lack of archaeological knowledge.

Returning to the Romanian autochthonist narrative, in which the Romans were the invaders and civilizers of the local tribes, we are still not entirely clear on what happened to the local Dacians after the Romans arrived (see Oltean 2007). It is certain, however, 
that an argument for a pure Roman heritage precludes any local element. This trend continued into the early nineteenth century, spreading to Transylvania, which was then ruled from Vienna by the Austro-Hungarians, where Greek Catholic intellectuals ${ }^{6}$ used the idea of Roman origin to argue for autonomy from Hungary. The grandeur of Rome so impressed Samuil Micu (1745-1806), Gheorghe Şincai (1754-1816), and Petru Maior (1756-1821) that they used "mastery histories and pioneering grammars [to define] the uniqueness of the Romanian ethnic community" as the heirs to the Roman Empire (Niculescu 2001: 92; cf. Deletant 1991). Micu in particular linked the origins of the Romanian history to the foundation of Rome by Romulus and Remus, arguing that the line of descent was continuous since Trajan must have exterminated the Dacians (Micu 1792, translated in Niculescu 2001). They all employed linguistics to support their theories, attempting to replace the traditional Cyrillic alphabet with Latin. Maior wrote the Lexicon de Buda in 1825, arguing that Romanian was derived from a 'Vulgar Latin,' whilst attempting to replace all foreign words with those of Latin origin (Niculescu 2001). This combination of history and language corresponded to the popular notion of the nation as a people, united on the basis of common origins, in a community with a shared language and history. The Transylvanian School considered the Romanians to exist as a unified people throughout Transylvania, Wallachia, the Maramures, Moldavia, and the Banat, separated only by externally imposed political boundaries (see Fig. 2).

The Latinist School followed the Transylvanian School in seeking the continued spread of this Romanian heritage. Between 1830 and 1860 interpretations of the Romanian past that do not uphold Latin purity are almost non-existent. Boia (2001: 87) describes the aims of the Latinists succinctly, "the excellence of the foundation myth guaranteed the excellence of the Romanian future, in spite of the mediocrity of the present. Through the Romans, the Romanians could present themselves as the equals of anybody." In 1853, August Treboniu Laurian published his History of the Romanians which began with the foundation of Rome in 753 BCE. This idea of equating Romanian history with Roman was not without dissent from Romanian scholars, who became increasingly vocal after Laurian also tried to create a nonsensical "artificial language" out of Romanian, purified from non-Latin elements. Boia argues that Laurian's work was both the "highest expression" of Latinism, while also its "swan song" (2001: 87).

The autochthonous element began to return in 1857, when Brătianu published his Historical Studies on the Origins of our Nationality, which argued that the Romanians descend from the Thracians, Celts, and the Romans. This had clear political motives, as the Thracians (and thus the Dacians) symbolized longevity in the land, while the Romans granted the aura of civilization, and Celts (or the Gauls) linked the Romanians to the culturally admired French. Scholars largely focused, however, on the role of the Dacians in comprising Romanian identity, and began to question the work done by the Latinists. In 1860 B. Hașdeu thoroughly debunked their efforts by proving they had built the

\footnotetext{
6 The Greek Catholics, also known as Uniates, were a separate sect of Orthodox Catholics who recognized the authority of the Pope and Catholic dogma, but likewise included Byzantine rather than Latin rites; their church was formally established in 1596.
} 
entire thing based on a forced interpretation of ancient sources (Boia 2001). His work Did the Dacians Perish? ascertained that the Dacians survived the Romans, which opened up a whole new world of possibilities for the Romanian national narrative. Trencsényi (2011: 23) describes Hașdeu as representing the "Romantic-liberal heritage" but turned it to a more "directly ethnicist direction". This was an almost parallel contrast to M. Eminescu (1850-1889), the eminent Romanian poet of the nineteenth century who came from a Junimist critique of liberal nationalism (Trencsényi 2011). Trencsényi (2011: 22) writes that Eminescu's "sociological insights crystallized around a single dichotomy: the conflict between the 'positive classes' and the 'superimposed strata,' that is, the autochothonous and the alien." He is especially important in the entangled narrative of Romanian historiography and nationalism because his work "helps us understand how the political projects, the historical narratives and the normative discourse of the 'national self mutually conditioned each other" (Trencsényi 2011: 23). Although he followed in the "intellectual tradition of Vico, Montesquieu, Herder...Hegel, and Comte," Hașdeu also pioneered the intellectual engagement between Romania and the Slavic East Central Europe, referencing Slavic studies in his own work (Trencsényi 2011: 24). Hașdeu's education provides clues as to why he took such an alternative view. He was from northern Bessarabia, which was then part of the Russian Empire, and was educated at Kharkiv University in Ukraine (Marinov 2015). His work embodies changing perceptions about the origins of the Romanians. Hașdeu initially rejected the idea of Dacian Latinization, but believed that "ethnic fusion was part of the formation of [the] Romanian nation" (Trencsényi 2011: 27). He later became more accepting of the 'Dacian vision' and as Trencsényi (2011: 27) writes, "turned to an autochthonist narrative of ethnogenesis."

Scholars had considered the Dacians as possible ancestors of the Romanians in the previous century, ${ }^{7}$ but dismissed them for various reasons. One thought the Dacians were unsuitable because they were Scythians and worshipped the Slavic gods (Marinov 2015: 23). Verdery (2001: 36-7) notes that the Dacians,

made greater headway once the creation of a Romanian state had diminished the need to gain European support for independence...unlike Latinism, Dacianism meant independence in politics, for preRoman Dacia bad been powerful within its region and had even exacted tribute for a time from Rome.

Furthermore, the Dacians were seen to have had a deeper, more intangible and spiritual connection with the land, in line with Romantic nationalist thought (Zub 1981). There were specific political advantages to such a claim- Hungary had previously justified ownership of Transylvania by claiming it was empty when the Magyar nomads entered in 896 CE. The old theory that the Romans exterminated the Dacians did not give the Romanians much of an argument, as it was well known the Romans abandoned Dacia in

\footnotetext{
${ }^{7}$ Actually, Greek intellectuals like D. Philippide, D. Fotino used 'Dacia' in the first half of the 19th century to refer to the modern Romanian space, and accepted the idea of Daco-Roman mixing (Marinov 2015: 23).
} 
271 CE. ${ }^{8}$ If, however, instead, the Romans and the Dacians interbred, then it was logical that a Dacian population would remain after the Roman retreat in their homeland of Transylvania (Verdery 2001). Furthermore, the Dacians provided a new aspect of longevity to Romanian identity. Through this mysterious people, scholars could trace a lineage back into the mists of history rather than relying on the concrete timeline of the Romans. As the Dacians began to appear in the national past, archaeological work also began to appear as a means of accessing a people who appeared far less frequently in written sources than the Romans. Such a trend is reflected upon in the work of Enea (2012: 94), who writes, "the emergence of archaeology in Romania is linked to the search, development, and affirmation of the national identity." In 1858, C. Bolliac (18131881) began an amateur archaeological quest to find the remains of the ancient Dacians, emphasizing that, "[Our] nobility is as old as the soil..." (as translated in Boia 2001: 92). Bolliac defined 'Romanianness' in terms of "climatic determination, stressing that the Romanians were fatally wedged between the poles of north and south, past and future, archaism and modernity." (Bolliac in Boia 2001: 92). He situated Romania spatially between the West and the East, blaming the "capricious national character" on the "mixing of barbarism and civilization, Orient and Occident" (Trencsényi 2011: 6). For Bolliac, to be on the margins of Europe and susceptible to Eastern influences was at least partially to blame for the contemporary backwardness of Romania. The mission of Romanian archaeology was to stir up the Dacian substratum, previously overshadowed by the brilliance of the Romans, as a way of emphasizing the 'pre-Ottoman' Romanian past. Marinov (2015: 23) writes that Bolliac admired the Dacians because they were a "big and powerful nation, with a sublime religion based on a belief in immortality", and because they were also apparently the first to convert to Christianity.'

Continuing Bolliac's work, A. Obobescu taught the first course in archaeology at the University of Bucharest in 1874. Enea (2012: 94) writes that "he was the first to introduce scientific methods into the archaeological approach [in Romania]." G. Tocilescu published the first synthesis of Romanian historiography in 1880, stressing the Dacians over the Romans, or Dacia before the Romans (Enea 2012; O Riagain \& Popa 2012; Marinov 2015). He scorned the idea that the Getae ${ }^{10}$ and Dacians were German/Gothic, Celtic, or Slavic, and asserted their Thracian character (Marinov 2015). Tocilescu specifically did not equate the Getae and the Dacians, preferring the later as they were "morally purer" (Marinov 2015: 25). Nonetheless, subsequent Romanian historiographical works treated the Getae and the Dacians as the same people. Despite the lack of clarity regarding the identity of Dacians, it was impractical for academics to wholly abandon the notion of Roman descent. The new theory henceforth became

\footnotetext{
8271 CE is the common date for Aurelian's abandonment of Dacia, it may have occurred up till 275 (Ellis 1998).

${ }^{9}$ Herodotus (4.93) writes, "Their [the Getae] belief in their immortality is as follows: they believe that they do not die, but that one who perishes goes to the deity Salmoxis, or Gebeleizis, as some of them call him."

10 The Getae are a Thracian tribe which once lived in the region of the lower Danube, known from ancient sources like Strabo (7.3.13) who described them as a people separate from the Dacians. Romanian historiography, however, tended to treat the two as one in the same, creating the united 'Geto-Dacian's' which provide the autochthonous connection to the national space (Niculescu 2004).
} 
known as "Daco-Roman continuity," which alleged the intermixing of Roman and Dacian and granted the Romanians the benefits of a less rigid identity, which nonetheless sustained their marginal European identity.

\section{Romanian National Space post-Independence}

The shift from a pure Latin inheritance to varying degrees of Dacian only occurred after the Romanians began to achieve political independence. Despite a failed revolution in 1848, 1859 saw the formal union of Wallachia (modern Oltenia and Muntenia, see Fig. 2) and Moldavia in the "United Principalities of Romania," with the "Kingdom of Romania" emerging in 1881 upon the addition of Dobrogea. These original forays into Romanian identity were all results of early attempts to appeal to an international audience. Initially the Moldavian Latinists sought Western aid for the 'sons of Rome' against Ottoman oppression, and the Latinists sought to solidify Romanian identity as older and more civilized than that of the Hungarians. Romanian scholars turned towards a Dacian origin only after Romania gained some political independence. Dacia was more of a 'manifest destiny', a call to the homeland in accordance with the contemporary idea that people's souls are formed by the soil on which they are born (Verdery 1991). According to the principles of ethnic nationalism, if Romania wanted to claim territory from Hungary, they had to prove that their people had an older claim to that land. Since the time at which the Romans entered into the Carpathians is well documented, the Romanians had, instead, to use the less tangible longevity of the autochthonous Dacians to preempt the Hungarian Magyars.

Romania gained significant political power by the beginning of the twentieth century. Prior to First World War they controlled Moldavia, Wallachia, and Dobrogea, ${ }^{11}$ they were allied with Austro-Hungarian Empire, and they were on a broadly level playing field with other European nations. The emphasis on Romanian identity changed from Latin purity and continuity to a reflection of a time in the past when the 'Romanians' had political independence. In other words, the new Romanian state was the heir to the Dacian 'nation' that the Romans had encountered in the $1^{\text {st }}$ century CE. This Dacian nation was,

no mere agglomeration of a number of savage tribes with a shifting population, scattered loosely over extended territory with a complete lack of political and national cohesion such as the Romans had found in Dalmatia or Thrace or Pannonia or Moesia; here was a nation, organized, powerful, conscious of itself (Pârvan as translated in Boia 2001: 95).

Not only was Dacia supposedly more advanced than the other tribes in the region, it displayed a level of cohesion remarkable for Iron Age tribes in the Carpathian Basin. Vasile Pârvan (1882-1927), as quoted above, wrote the seminal work on Romania's Dacian heritage, in which he outlined an image of Dacian civilization similar to the current perception of traditional Romanian culture. Pârvan went on to become "the

11 They annexed Southern Dobrogea in 1913 after allying with the Greeks and the Serbians to defeat the Bulgarians in the $2^{\text {nd }}$ Balkan War. 
patriarch of the Romanian archaeological establishment," conducting pioneering excavations at the Roman city of Histria on the Black Sea coast (Kaiser 1995: 101). His work, which according to Boia (2001: 95; see also Iordachi and Trencsenyi 2003: 428) was "unassailable from a methodological point of view," suggested that the Romanian nation-state "has been a 'natural' and 'objective' historical outcome of the struggle for political union." Pârvan is not alone for assuming a 'natural' national evolution. The nation as a "human constant" was a prevalent attitude among the scholarly community for much of the early-mid twentieth century, with scholars often deploring its harmful effects yet taking it for granted (Smith 1986: 7).

In the years immediately after First World War, Romania achieved its greatest territorial extent, adding the territories of Banat, Bessarabia, Bukovina, and Transylvania. The country then became known as România Mare or 'Greater Romania'. Despite the obvious success of the 'heirs' of the Dacians, not everyone agreed with a solely Dacian heritage; after all, the Romans were still the great civilizers, and fledgling Romania was not yet so powerful that it could abandon the notion of a common European heritage. The theory of Daco-Roman continuity therefore provided a common ground for emphasizing the Dacians, while still recognizing the positive influence of the Romans. Most importantly, it allowed for the continued perception that the Romanians were the "Romance Island set in the heart of a Slavic sea" (Light \& Dumbraveanu-Andone 1997: 31). Ideological separation from the Hungarians remained important, as Romania had only recently received the territory of Transylvania which had a significant Hungarian population clamoring for autonomy (Brubaker 2006).

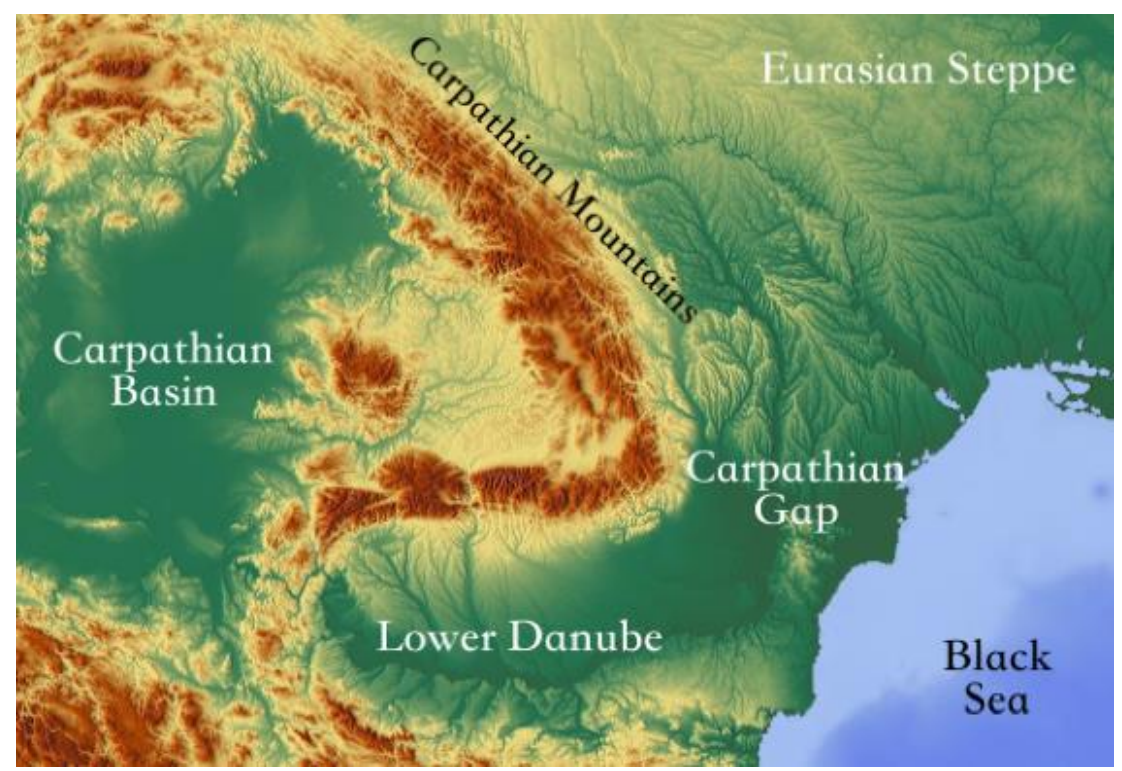

Figure 4. Geographic regions, map by E. Hanscam, data (C) OpenStreetMap contributors, CC-BY-SA 2.0
Romania's Roman past also received much international attention during this period, as Seton-Watson, a professor at the University of London wrote, "we are dealing with perhaps the most obscure corner of Western history . . .there is simply no parallel for the mysterious silence which surrounds the Romanians in the thousand years following the withdrawal of Aurelian and his legions" (Seton-Watson 1934: 192). These international academics also projected the Romanians backwards into history, attempting to understand the modern success of the Romanian nation through a long-term civilizing process that began in antiquity. 
The most important aspect of Romanian nationalism is its continued propagation of an ideology, which grounds the nation as a frontier. Romania is on the margins of Europe, defending the borders of the West from eastern incursions. Romania is also the center of Latinity surrounded by Slavic nations, and it must therefore defend its national borders just as the nation itself is in turn defended as a border of Europe. The geography of the region (Fig. 4) facilitated centuries of cultural interactions which used the natural features (the Danube, the Carpathian Mountains) to their advantage. In this sense the physical landscape is key to the frontier identity, with the river barriers that invited fortifying or the mountains and sea which channeled migrations along certain routes. In the 1920s V. G. Childe referred to the Balkans as the 'bridge' between Europe and the Near East during the Neolithic, and it is apparent that Romania along with Bulgaria will continue to play a key role in the relationship between Europe and the Near East, as well as the European Union and the Russian sphere; making it vital that we understand the intellectual process behind the creation of the modern nation.

\section{The Roman Limes and Ideological Frontiers}

As outlined above, from the eighteenth century onwards, Romania has intentionally created itself as a border nation, taking advantage of the marginal identities of, first the Romans (marginal in respect to their more-recent Ottoman past), then the Dacians, and finally, a combination of the two in the Daco-Romans. Romania has a diverse, vibrant, and tenacious population, but the nationalist rhetoric continues to emphasize the Latin and native element over anything Slavic or Ottoman (Niculescu 2002). This is partially due to the overwhelming presence of the Roman-Dacian narrative on the physical landscape. Romania contains some of the most extensive Roman fortification networks in Europe (Oltean 2007). Levels of archaeological investigation vary from the wellstudied Sarmizegetusa Regia and nearby settlements in the Dacian heartland of the Orăştie Mountains (Diaconescu 2004; Oltean 2007; Fodorean et al. 2013), to the Roman fortifications of Dobrogea, of which a few have extensive research histories, ${ }^{12}$ but many remain practically untouched. The Roman Limes fall into this latter category, but can offer insight into how the lower Danube frontier reinforces Romania's defensive, border nation agenda.

The Roman frontier on the lower Danube, also known as the Moesian Limes (Fig. 5), consists of a series of fortifications stretching from Singidunum (modern Belgrade) to Halmyris in the Danube Delta (Whittaker 1994). The entire region is not actually a national boundary - a section of the Limes lies downstream from where the Danube and by extension the Limes form the Romanian-Bulgarian border. Most important is how archaeologists and frontiers continue to interact. I believe that the Roman archaeologist travelling to Dobrogea views the landscape as a military frontier, focusing on a relatively brief period of time in the past, connecting it to what they see in the present. Related to the concept of 'being in the world', which Thomas (2012) argues is fundamentally a

\footnotetext{
12 See Wilkes 2005 for a summary on the Roman Danube; Hanson and Oltean 2012 on the Valu lui Traian; Lockyear 2002 and Lockyear et al. 2005 for excavations at Noviodunum; Zahariade \& Phelps 2002, Zahariade 2013, Zahariade \& Karavas 2015 for excavations at Halmyris
} 
relational involvement, the physical remnants of the Limes are powerful symbols in otherwise foreign landscapes. Standing on unexcavated forts like that of Salsovia, looking across the Danube (see Fig. 6), a Roman archaeologist cannot help but relate their knowledge of antiquity to where they are in the present. They experience the Lower Moesian Limes through the lens of other Roman frontiers, exemplified by recent attempts to unite them all in one pan-continental UNESCO World Heritage Site (Hingley 2015). Frontiers are all about perspective, and archaeologists focusing on the Roman frontier look outward to see what the fortifications are defending against. In this region we know that the Roman legions focused primarily on the tribes north of the Danube (Zahariade \& Gudea 1997). By experiencing the landscape through the aim to view, understand, or excavate the frontier as a conflict space, archaeologists are reinforcing Romania's self-identification as a border region, still poised to defend from threats beyond the Danube. During 2014-2015, the early years of the conflict in Ukraine, the potential for a threat to Romania beyond the eastern Danube became a bit more real.

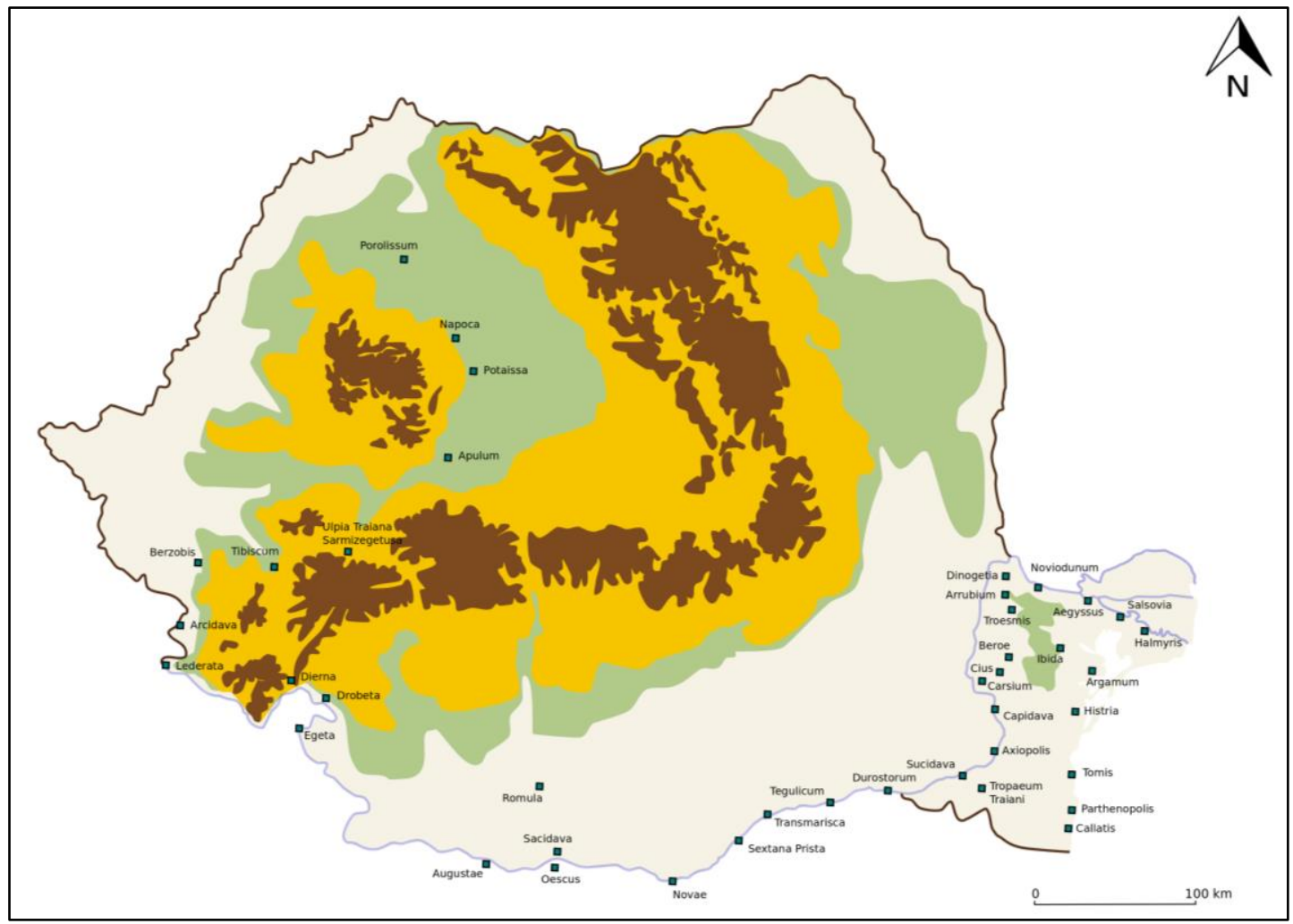

Figure 5. The principal Roman sites in Romania including the Lower Danube Limes (E. Hanscam).

The present consensus is that frontiers must be understood as zones of interaction, places where cultures meet and form something new and unique, a hybrid in-between space (Naum 2010). Hingley $(2012,2015)$ has repeatedly called for recognition of the multivocality of Hadrian's Wall, and recent scholarship has embraced the potential of the Hadrian's Wall landscape for looking critically at cross-cultural interaction (see e.g. Nesbitt \& Tolia-Kelly 2009; Witcher 2010; Hingley et al. 2012). The Lower Moesian Limes have similar potential to inspire the view of Dobrogea as a unique 'Third Space' (sensu Bhabha 2004), a place of "constant dialogue and remaking" (Naum 2010: 106). 
This will not happen, however, until the Limes are reconnected to their contemporary social landscape and studied as living fortifications, which were also places of meeting and exchange, and not just for the military. Until recently, military history has been the primary focus for archaeological work done on the lower Danube frontier, although at Halmyris archaeologists are beginning investigations into the extensive civilian settlement, which will be useful as a potential reference for other studies in the region (Karavas \& Zahariade 2017). The Lower Moesian Limes were built by the Roman Empire to aid in provincial defense, however, like Hadrian's Wall, they became the material foundations supporting a Third Space landscape. They exist today as the living embodiment of the Romanian nationalist narrative, one that is militaristic and defensive, because there has been no research to highlight the multicultural aspects of this frontier. If we want to combat this, we must understand the Lower Moesian Limes as an ideological frontier from a postcolonial and globalist theoretical perspective.

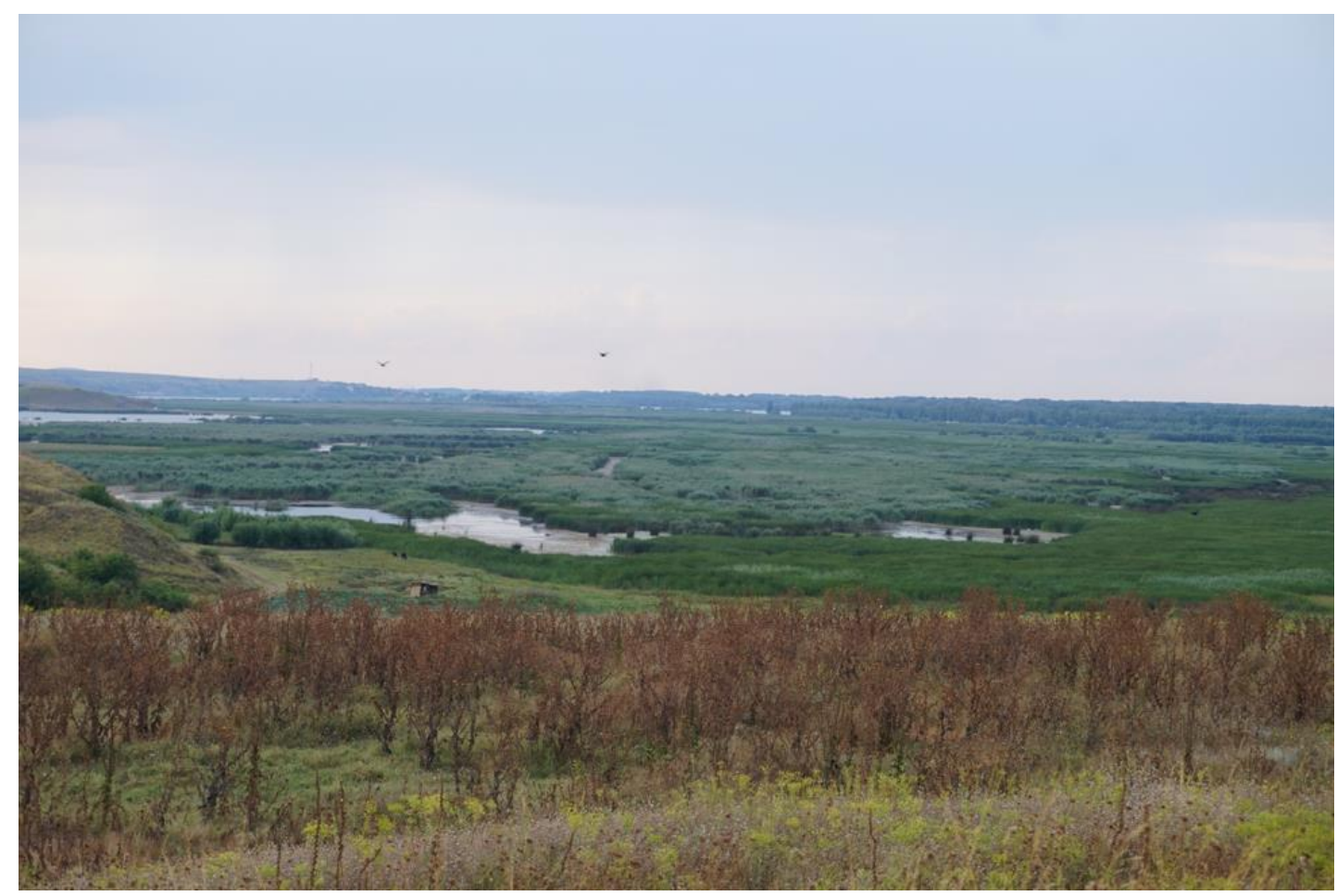

Figure 6. Looking north across the Danube from Salsovia (E. Hanscam).

Ideological frontiers are commonly understood as non-physical boundaries, like geographical frontiers, they are multidimensional and "places of manifold realities" (Naum 2010: 102). Postcolonial theory is one currently popular way to approach both frontiers and Roman archaeology, although as Hingley (2014) points out, while Roman scholars have, in recent years, begun to consider globalization theory (see e.g. Pitts \& Versluys 2015); neither postcolonial theory nor globalization are mutually exclusive to the other, nor are they a linear theoretical progression. Both have equal potential for understanding multidimensional spaces such as the Lower Moesian Limes. Gardner (2013) argues for a holistic approach that includes both, noting that while Roman archaeology is theoretically lacking compared to many other periods of focus, there is nevertheless great potential for theoretical innovation. Postcolonial theory gives us the 
ability to "describe the diversity and shiftiness of inter-human and human-object interactions in the borderlands" (Naum 2010: 106). Globalization, on the other hand, "is a long-term historical phenomenon" that emphasizes pluralism and multiculturalism, while permitting a "diversity of responses to the Roman past" (Witcher 2015: 200, 215). We need to ground studies of the lower Danube frontier with local experiences, recognizing the uniqueness of the interactions taking place, but also understanding its role as a multicultural phenomenon with a living history.

\section{Conclusion}

It is easy to dismiss overtly biased or agenda-filled archaeologies, but by doing so we fail to fully understand the nationalist context that often inspires such work. As Popa (2015) writes, archaeology in Romania and Romanian nationalism had a reflexive and reciprocal relationship which continues today. The lower Danube Roman frontier is ripe for archaeological work which will focus on its multivocal history, but the decades of Roman and Dacian entanglement with Romanian identity make it difficult for new theoretical perspectives to gain real momentum. Romania sees itself as a defensive frontier space rather than a frontier in the sense of a multicultural zone of interaction, and because of this, the archaeological work done on the Lower Moesian Limes takes a similar military-centered viewpoint. Romania is a frontier in many senses of the word: in terms of self-identity, cross-cultural interactions from antiquity to the present day, the materiality of the Roman landscape, and even as a place where archaeologists continue to confront embedded notions of how the past ought to relate to the present. Ideological space is complex, as it can pose as a real barrier to the movement of people. Consequently, we should make every effort to comprehend how it was created and how it functions today. Archaeologies and other narratives of the past play a critical role in this, and as shown with the lower Danube, ideological frontiers likewise support archaeological work congruent with the dominant ideology. The prospect of continued mass migration along with the disintegration of the European Union makes it increasingly important that we question such ideologies and the national spaces they sustain, focusing in particular on the entanglement of frontiers both in the past and the present.

\section{References}

Alberti, B., S. Fowles, M. Holbraad, Y. Marshall \& C. Witmore, 2011. "Worlds Otherwise": Archaeology, Anthropology, and Ontological Difference. Current Anthropology 52(6): 896-912.

ANDERSON, B., 2006. Imagined Communities. London: Verso.

BHABHA, H., 2004. The location of culture. London: Routledge.

BOIA, L., 2001. History and myth in Romanian consciousness. Budapest: Central European University Press.

Brubaker, R., 2006. Nationalist Politics and Everyday Ethnicity in a Transylvanian Town. Princeton: Princeton University Press.

CHILDE, V.G., 1958. The prehistory of European society. Nottingham: Spokesman Books. 
CurTA, F., 2001. The Making of the Slavs: History and Archaeology of the Lower Danube Region c.500-700. Cambridge: Cambridge University Press.

Deletant, D., 1991. Rewriting the past: trends in contemporary Romanian historiography. Ethnic and Racial Studies 14(1): 64-86.

De Francesco, A., 2013. The Antiquity of the Italian Nation: The Cultural Origins of a Political Myth in Modern Italy, 1796-1943. Oxford: Oxford University Press.

Diaconescu, A., 2004. The towns of Roman Dacia: an overview of recent archaeological research, in: HANSON, W. \& HAYNES, I. (eds.), Roman Dacia, the making of a provincial society. Journal of Roman Archaeology Supplemental Series 56. Portsmouth, RI: Journal of Roman Archaeology, 87-142.

Diaz-Andreu, M., 2008. A World History of Nineteenth Century Archaeology: Nationalism, Colonialism, and the Past. Oxford: Oxford University Press.

Diaz-Andreu, M. \& T. Champion, 1996a. Nationalism and Archaeology in Europe: an introduction, in: M. DiAZ-ANDREU \& T. CHAMPION (eds.), Nationalism and Archaeology in Europe. London: UCL Press, 1-23.

Diaz-Andreu, M. \& T. Champion (eds.), 1996b. Nationalism and Archaeology in Europe, London: UCL Press.

Dragoman, A., 2009. Ideology and politics in researching the (E) Neolithic in Romania. Dacia LIII: 167-189.

ELLIS, L., 1998. 'Terra deserta': population, politics, and the [de]colonization of Dacia. World Archaeology 30(2): 220-237.

ENEA, S.C., 2012. Romanian Prehistoric Archaeology, between tradition and innovation. Археологія і давня історія України 902(091): 93-102.

Fodorean, F., I. Fodorean \& C. Moldovan, 2013. Recreating the landscape of the former Roman Dacia using modern $19^{\text {th }}$ century cartography, digital data and GIS. $e$ Perimetron 8(1): 37-55.

GARDNER, A., 2013. Thinking about Roman Imperialism: Postcolonialism, Globalisation and Beyond? Britannica 44: 1-25.

GARDNER, A., 2017. Brexit, boundaries and imperial identities: A comparative view. Journal of Social Archaeology 17 (1): 3-26.

Gonzalez Morales, M. \& M. Fano Martinez, 2005. The Mesolithic of Cantabrian Spain: a critical review, in N. MiLner \& P. WoOdman (eds.), Mesolithic Studies at the beginning of the $21^{\text {st }}$ Century. Oxford: Oxbow Books, 14-29.

HAMILAKIS, Y., 1996. Through the looking glass: nationalism, archaeology and the politics of identity. Antiquity 70: 975-978.

Hamilakis, Y., 2007. The Nation and Its Ruins. Oxford: Oxford University Press.

HANSON, W. \& Haynes, I. (eds.), 2004. Roman Dacia, the making of a provincial society. Journal of Roman Archaeology Supplemental Series 56. Portsmouth, RI: Journal of Roman Archaeology.

HAMILAKIS, Y., 2017. Archaeologies of Forced and Undocumented Migration. Journal of Contemporary Archaeology 3(2): 121-139

Hanson, W. \& I. OltEAn, 2012. The "Valu lui Traian": a Roman frontier rehabilitated. Journal of Roman Archaeology 25(1): 297-318.

Hingley, R., 2000. Roman Officers and English Gentlemen. London: Routledge. 
Hingley, R., 2015. Working with Descendant Communities in the Study of Roman Britain, in Cipolla, C. \& K. HOwLETT HAYes (eds), Rethinking Colonialism: Comparative Archaeological Approaches, Gainesville: University Press of Florida, 161-190.

Hingley, R., R. WiTCHER \& C. NESBITT, 2012. Life of an ancient monument: Hadrian's Wall in history. Antiquity 86: 760-771.

Hitchins, K., 1992. Historiography of the Countries of Eastern Europe: Romania. American Historical Review 97(4): 1064-1083.

HitCHINS, K., 1996. The Romanians: 1774-1866. Oxford: Clarendon Press.

Hitchins, K., 2001. The Idea of Nation among the Romanians of Transylvania, 1700 1849, in Nation and National Ideology: Past, Present and Prospects. Proceedings of the International Symposium at the New Europe College April 6-7, 2001, Bucharest, 78109.

Kobsbawm, E. \& T. Ranger, 1983. The Invention of tradition. Cambridge: Cambridge University Press.

HODDER, I., 2005. Theory and practice in archaeology. London: Routledge.

IORDACHI, C., 2004. "Entangled Histories:" Re-thinking the History of Central and Southeastern Europe from a Relational Perspective. Regio Yearbook: 113-147.

Iordachi, C. \& B. TREnCSÉnYI, 2003. In Search of a Usable Past: The Question of National Identity in Romanian Studies, 1990-2000. East European Politics and Societies 17(3): 415-453.

Kaiser, T., 1995. Archaeology and ideology in southeast Europe, in: KoHL, P. \& FAWCETT, T. (eds), Nationalism, politics, and the practice of archaeology. Cambridge: Cambridge University Press, 99-119.

Karavas, J. \& M. Zahariade, 2017. Excavations at Halmyris: A Field Report of the 20142016 Seasons. Paper presented to the Annual Meeting of the Archaeological Institute of America, Toronto, 5-8 January 2017.

KOHL, P.L., 1998. Nationalism and Archaeology: On the Constructions of Nations and the Reconstructions of the Remote Past. Annual Review of Anthropology 27(1): 223-246.

LAmpe, J. \& M. Mazower, 2004. Ideologies and national identities. Budapest: Central European University Press.

Light, D. \& D. Dumbraveanu-Andone, 1997. Heritage and National Identity: Exploring the relationship in Romania. International Journal of Heritage Studies 3(1): 28-43.

LOCKYEAR, K., 2003. At the edges of empires: the Noviodunum project, Romania. Archaeology International 2002/3(6): 21-24.

LOCKYEAR, K., 2004. The Late Iron Age background to Roman Dacia, in: Hanson, W. \& HAYNES, I. (eds.), Roman Dacia, the making of a provincial society. Journal of Roman Archaeology Supplemental Series 56. Portsmouth, RI: Journal of Roman Archaeology, 33-74. Lockyear, K., T. Sly \& A. Popescu, 2005. The Noviodunum Archaeological Project 2000-2004: results and conclusions from the pilot seasons. Peuce (Serie Nouă)-Studii şi cercetari de istorie şi arheologie 3 (3-4): 121-158.

MARAN, J., 2017. Later Balkan prehistory, a transcultural perspective, in: M. GORI \& M. Ivanova (eds.), Balkan Dialogues, Negotiating Identity between Prehistory and the Present. London: Routledge. 
MARINOV, T., 2015. Ancient Thrace in the Modern Imagination: Ideological Aspects of the Construction of Thracian Studies in Southeast Europe (Romania, Greece, and Bulgaria), in Daskalov, R. \& A. Vezenkov, (eds.), Entangled Histories of the Balkans, Vol. III: Shared pasts, disputed legacies. Leiden: Brill, 10-118.

Matei-Popescu, F., 2010. The Roman Army In Moesia Inferior. Bucharest: Conphys Publishing House.

MCGuiRe, R., 2008. Archaeology as political action. Berkeley: University of California Press.

MeLLARS, P., 2006. A new radiocarbon revolution and the dispersal of modern humans in Eurasia. Nature 439: 931-935.

Mishrova, D., 2015. The Afterlife of a Commonwealth: Narratives of Byzantium in the National Historiographies of Greece, Bulgaria, Serbia, and Romania, in R. DASKALOV \& A. VEZENKOv (eds.), Entangled Histories of the Balkans, Vol. III: Shared pasts, disputed legacies. Leiden: Brill, 118-273.

Mishkova, D. \& R. Daskalov, 2014. "Forms without Substance": Debates on the Transfer of Western Models to the Balkans, in: R. DASKALOV \& D. MishKOva (eds.), Entangled Histories of the Balkans, Vol. Two. Leiden: Brill, 1-98.

NAum, M., 2010. Re-emerging Frontiers: Postcolonial Theory and Historical Archaeology of the Borderlands. Journal of Archaeological Method and Theory 17(2): 101-131. NesBitT, C. \& D. ToliA-Kelly, 2009. Hadrian's Wall: Embodied archaeologies of the linear monument. Journal of Social Archaeology 9(3): 368-390.

Niculescu, G., 2002. Nationalism and the Representation of Society in Romanian Archaeology, in: Nation and National Ideology: Past, Present and Prospects. Proceedings of the International Symposium at the New Europe College April 6-7, 2001. Bucharest, 209234.

Niculescu, G., 2004. Archaeology and Nationalism in 'The History of the Romanians.' Dacia XLVIII: 99-124.

O’ Riagain, R. \& C. N. PopA, 2012. Archaeology and Nationalism in Europe: Two Case Studies from the Northwest and Southeast of Europe. Archaeological Review from Cambridge, 27(2): 52-71.

PITTS, M. \& M. VersLuYs (eds), 2015. Globalisation and the Roman World. Cambridge: Cambridge University Press.

PopA, C. N., 2015. Late Iron Age Archaeology in Romania and the Politics of the Past. Dacia LIX: 337-361.

Preucel, R. \& L. Meskell, 2004. Knowledges, in: R. Preucel \& L. Meskell (eds.), A Companion to Social Archaeology. Oxford: Blackwell Publishers, 3-22.

Richardson, T., 2013. Borders and Mobilities: Introduction to the Special Issue. Mobilities 8(1): 1-6.

SAssen, S., 2008. Territory, Authority, Rights: From Medieval to Global Assemblages. Second Edition. Princeton: Princeton University Press.

Seton-Watson, R.W., 1934. A History of the Roumanians. London: Cambridge University Press.

SMITH, A., 1986. The Ethnic Origins of Nations. Oxford: Blackwell Publishers.

SpINEI, V., 2009. The Romanians and the Turkic Nomads North of the Danube Delta from the Tenth to the Mid-Thirteenth Century. Leiden: Brill.

StRAssLer, R., 2007. The Landmark Herodotus. trans. Purvis, A.L. London: Quercus. 
TANaȘOCA, N., 2002. L’image Roumaine de Byzance à l'époque des Luminères, in: Theodoresu, R. \& L. C. BArrows (eds.), South-East Europe: The Ambiguous Definitions of a Space. Bucharest: UNESCO-CEPES, 47-75.

TANAŞOCA, N., 2014. Byzance dans la conscience historique des Roumains, in: O. Delouis, A. Couderc \& P. Guran (eds.), Héritage de Byzance en Europe du Sud-Est, Athens: École française d'Athènes, 269-271.

Thomas, J., 2004. Archaeology and modernity. London: Routledge.

Thomas, J., 2012. Archaeologies of Place and Landscape, in: HodDER, I. (ed.), Archaeological Theory Today. Second Edition. Cambridge: Polity, 167-187.

Todorova, M., 2009. Imagining the Balkans. Updated Edition. Oxford: Oxford University Press.

TrencsÉnYI, B., 2010. "Imposed Authenticity": Approaching Eastern European National Characterologies in the Inter-war Period. Central Europe 8(1): 20-47.

TrencsénYI, B., 2011. History and Character: Visions of National Peculiarity in the Romanian Political Discourse of the $19^{\text {th }}$ century, in: D. Mishkova (ed.), We, the People: Politics of National Peculiarity in Southeastern Europe, Budapest: Central European Press, $3-$ 36.

Trigger, B., 2006. A history of archaeological thought. Cambridge: Cambridge University Press.

Trinkaus, E., S. Milota, R. Rodrigo, G. Mircea \& O. Moldovan, 2003. Early modern human cranial remains from the Peştera cu Oase, Romania. Journal of Human Evolution 25: 245-253.

VERDERY, K., 1991. National ideology under socialism: Identity and Cultural Politics in Ceausescu's Romania. Berkeley: University of California Press.

WATTS, C., 2014. Relational archaeologies: humans, animals, things, London: Routledge.

WhitTAKeR, C. R., 1994. Frontiers of the Roman Empire. Baltimore: The Johns Hopkins University Press.

WiLKeS, J., 2005. The Roman Danube: An Archaeological Survey. The Journal of Roman Studies 97: 124-225.

Witcher, R., 2010. The fabulous tales of the common people, part 1: representing Hadrian's Wall. Public Archaeology 9(3): 126-152.

WitcheR, R., 2015. Globalisation and Roman cultural heritage, in: M. PITTS \& M. VersluYs (eds), Globalisation and the Roman World. Cambridge: Cambridge University Press, 198-224.

Zahariade, I., 2013. From dava to civitas: Halmyris, a Getic, Early and Late Roman Settlement on the Lower Danube, in: G. Tsetskhladze, S. Atasoy, A. Avram, S. Dönmez \& J. Hargrave (eds.), The Bosporus: Gateway between the Ancient West and East (1 st Millennium BC-5th Century AD), Proceedings of the Fourth International Congress on Black Sea Antiquities Istanbul, 14th-18th September 2009, BAR International Series 2517, 207-212.

Zahariade, M. \& N. GudeA, 1997. The Fortifications of Lower Moesia (AD 86-275). Amsterdam: Adolf M. Hakkert.

Zahariade, M. \& J. Karavas, 2015. A Fort of the Danubian Roman Frontier: Halmyris, in: L. ZERBINI (ed.), Culti e religiosità nelle province danubiane. Atti del II 
Convegno Internazionale Ferrara 20-22 Novembre 2013. Bologna: Emil di Odoya, 575584.

Zahariade, M. \& M. Phelps, 2002. Halmyris, a settlement and fort near the mouth of the Danube: interim report. Journal of Roman Archaeology 15(1): 230-235.

Zenker, O., 2011. Autochthony, ethnicity, indigeneity and nationalism: Timehonouring and state-oriented modes of rooting individual-territory-group triads in a globalizing world. Critique of Anthropology 31(1): 63-81.

ZuB, A. 1981. A scrie și a face istorie. Istoriografia română postpașoptistă. Iași: Editura Junimea. 
